\title{
Estrogenicity and cytotoxicity of sediments and water from the drinkwater source-basin of Montevideo city, Uruguay
}

\author{
Griffero, L. ${ }^{1}$; Gomes, G. ${ }^{2}$; Berazategui, M. ${ }^{1}$; Fosalba, C. ${ }^{1}$; Teixeira de Mello, F. ${ }^{1}$; \\ Rezende, C.E ${ }^{3}$; Bila, D.M. ${ }^{2} \&$ García-Alonso, J. ${ }^{*}$ \\ ${ }^{1}$ Centro Universitario Región Este, Universidad de la República, Tacuarembó w/n and \\ Artigas, Maldonado 20000, Uruguay. \\ ${ }^{2}$ Laboratorio de Engenharia Sanitaria, Facultade de Engenharia, UERJ, RJ, Brasil. \\ ${ }^{3}$ Laboratorio de Ciencias Ambientais, Universidad Estadual do Norte Fluminense, Campos do Goytacazes, RJ, Brasil.
}

Received September 15, 2017; Accept February 16, 2018

\begin{abstract}
Frequently new pollutants are released into the environment, demanding the employment of generic methods to detect toxic responses. In vitro bioassays such as the yeast estrogenicity screening (YES) allow detecting estrogenic and citotoxic compounds avoiding the employment of invasive methods. We determined the cytotoxicity and estrogenic activity in sediments of the Santa Lucia River Basin (Uruguay) using YES assay and the association with land uses and parameters of water quality and sediment. Water quality parameters confirm the eutrophication process of the Santa Lucía River, which was mainly reflected

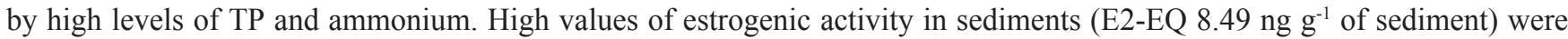
found mainly in urbanized and cultivated areas. However, estrogenicity and cytotoxicity also was found in sites associated with other land uses such as rangelands. These data provide evidence that Santa Lucía River basin contains a variety of chemicals (including estrogenic and toxic chemicals of unknown and potentially diverse sources) that should be investigated further. YES assay proved to be a useful tool for characterizing estrogenic responses, and due to the human and ecological health importance, we suggest the employment of these kinds of bioassays as tools for environmental monitoring of EDCs substances.
\end{abstract}

Keywords: Cytotoxicity; Estrogenicity; Pollution; Sediments; YES assay.

\section{INTRODUCTION}

Occurrence of compounds with estrogenic activity in surface waters has received much attention, mainly in relation to biological effects in aquatic organisms (Sumpter and Johnson, 2008). Estrogens can interfere in various processes linked to reproduction (e.g metabolic, morphological and behavioral changes) and development. For instance, disruption of estrogen signaling leads to impaired gonadal development, feminization, alteration of sex ratio in various species of fishes, and even generate changes at population level after exposure to a synthetic estrogen at sub lethal concentrations (Kidd et al., 2007; Söffker and Tyler, 2012). In addition, estrogenic chemicals can generate oxidative stress, and induce proliferation of estradiol dependent carcinomas (Ayoola et al., 2011; García-Alonso et al., 2011a; Thongprakaisang et al., 2013; Kabir et al., 2015).

Within estrogenic substances we can find compounds with different structures, including natural substances and a large number of synthetic compounds such as pesticides, surfactants, plasticizers, synthetic hormones, trace metals (De Coster and Van Larebeke, 2012), and even non-steroidal drugs widely used which estrogenic effects were reported recently (Efosa et al., 2017). These chemicals are introduced into the aquatic environment by domestic, agriculture or industrial human activities and might not be removed from the municipal wastewater and their consequences had become a concern (Zhang et al., 2011). In addition, some of them are 
used as chemical mixtures to enhance its action and can be more potent than individual components; so many evaluations could underestimates endocrine disruption effects if these inert ingredients are not taken into account (Vandenberg et al., 2017).

The precipitation and accumulation of these compounds in sediments increases the risk of exposure of organisms to cocktails of xenoestrogens (Wang et al., 2011) which may have additive or synergistic effects (Frische et al., 2009; Norris and Carr, 2006). For this reason is common to detect xenoestrogens in sediments of aquatic ecosystems associated with hazarous effects at different biological levels (GarcíaAlonso et al., 2011b; Wu et al., 2015).

Bioassays based on yeast strains such as the Yeast Estrogen Screen (YES) developed by Routledge and Sumpter (1996) are simple, easy handling and low costs non invasive tool for the determination of estrogenic activity (Rehmann et al., 1999). The YES assay is used to evaluate the estrogenic activity in waters and wastewaters (Dias et al., 2015; Rivetti et al., 2017).

Uruguayan water bodies present an actual degradation of their quality parameters, most of them related to eutrophication processess (Bonilla et al., 2015) principally due to agricultural intensification, dairy production and feedlots and low efficiency in sewage treatment plants. The biodegradation of EDCs may be influence by some of these quality parameters. For instance, the degradation rates of hormones are much higher under aerobic condition (Combalbert and HernandezRaquet, 2010), thus steroid estrogenic hormones are relatively stable over time and may accumulate in anaerobic or anoxic environments (Zheng et al., 2012).

In addition, no regulation in production, commercialization and use of already known EDCs exist in Uruguay. Therefore, there is an urgent need to analyze endocrine toxic responses that allow knowing the baseline of the estrogenicity of substances in water systems.

The aim of this study was to determine the estrogenicity and cytotoxicity of sediments of the Santa Lucia River using the in vitro YES assay and analyze the association with basin land uses and water quality.

Our hypothesis is that estrogenicity along the Santa Lucia River sediment is associated with different land uses (urban-industrial, agricultural and rangelands), since diffuse and multiple point sources of xenoestrogens according to land use.

\section{MATERIALS AND METHODS}

\section{Study area and sampling points}

The Santa Lucia River basin is located in the South of Uruguay $\left(33^{\circ} 41^{\prime} \mathrm{S} ; 54^{\circ} 59^{\prime} \mathrm{W}\right)$, comprise an area of 13448 $\mathrm{km}^{2}$ with a maximum altitude of 250 meters above sea level (Fig. 1). The basin drains into the estuary of the Río de la Plata and is a key estuarine site for conservation, since several

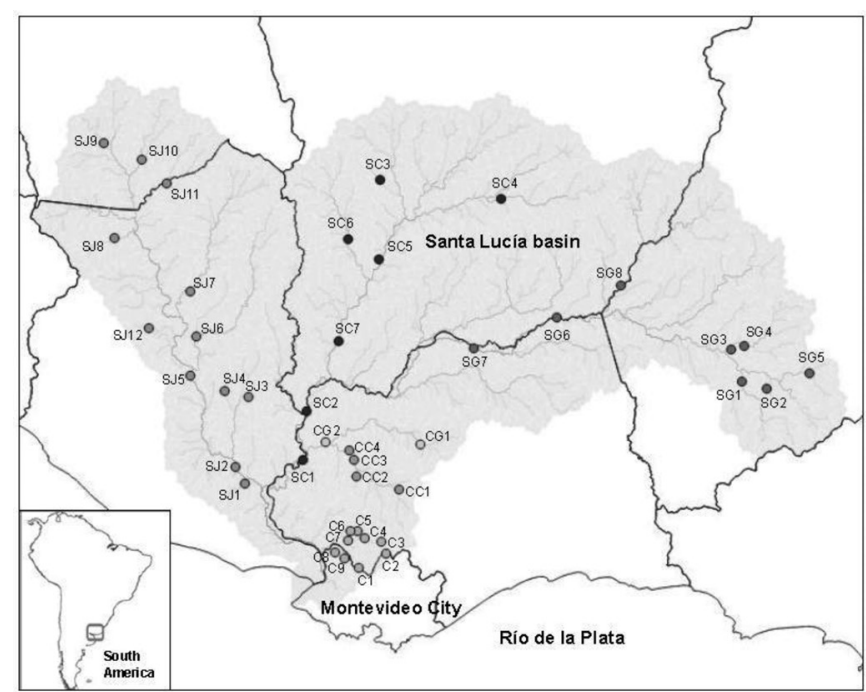

Figure 1. Map of the Santa Lucía river basin showing the sampling points. Different colours denote sub-basins. Delimitation of Uruguayan administrative regions (Departaments) are remarked.

estuarine and marine species including commercial and full exploited resources such as sciaenid fishes spawn in downstream waters of this river (Vizziano et al., 2001).

The watershed provides drinking water to more than $60 \%$ of Uruguayan besides being used as a water resource for irrigation in 6 administrative regions (Departments). Land uses in the catchment area of the basin include: cattle (71.3\%), agriculture $(16.2 \%)$, forestry $(4.2 \%)$ and finally the urbanindustrial (1.1\%) (Achkar et al., 2012).

Fourty two sampling points were selected covering a wide range of land uses and landscape heterogeneity (Fig. 1). Collection of samples was carried out in winter of 2014. The drainage area was estimated from a digital elevation model obtained from Nasa Shuttle Radar Topographic Mission (SRTM) data (Jarvis et al., 2008), using GRASS function 'r.watershed' in QGIS (Quantum GIS Development Team, 2015).

Main land use was estimated defining the area of land use by drawing polygons $(1 \mathrm{~cm}-11 \mathrm{Km})$ according to four mains categories: Agriculture, rangelands, forestry and urbanindustrial. Google Earth Pro free package was used. In order to see spatio-temporal variation and environmental partition of estrogenic compounds, three sampling points were analyzed in sediment and water (in triplicate) monthly from December 2014 to February 2015. Water and sediment were collected separately. Sites were located in the Santa Lucia Grande basin (SG1, SG2 and SG4). In all of them, the predominant land use associated was rangelands, but SG1 receives effluents from Mina's city while SG2 and SG4 represent sites with lower degree of anthropogenic impact.

\section{Water and sediment quality parameters}

In all site physico-chemical variables $(\mathrm{pH}$, dissolved oxygen, temperature and conductivity) were measured using field sensors and four water samples were taken to measure total phosphorous (TP), ammonium $\left(\mathrm{NH}_{4}^{+}\right)$, total suspended 
solids (TSS) and suspended organic matter (MOS) according to the standards of Valderrama (1981) and APHA (1985). At each sampling point, four sediment samples were also taken to measure organic matter percentage $(\% \mathrm{MO})$ and grain size (Phi). All fractions $>2 \mathrm{~mm}$ were separated by sieving in successive intervals, while fractions $<2 \mathrm{~mm}$ were determined with a laser diffraction particle analyzer (Shimadzu model SALD-3101). Three different certified samples were used to calibrate lasermethod (JISS 11, Licopodium and glass beads). Grain size was compiled in SYSGRAM 3.0 using the equation proposed by Folk and Ward (1957), using laser method in the Laboratory of Environmental Sciences (UENF, Rio de Janeiro-Brazil). This parameter was included as sorption capacity of some compounds like metals may differ at different sediment grain size (Ding et al., 2016).

\section{Sample treatment}

Before collection, all glass materials were previously rinsed with alcohol and acetone analytical grade (HPLC grade, Tedia). Superficial sediment and water samples were taken in amber glass bottles for the YES assay. Samples were transported on ice for no more than 4 hours, and stored at $-20^{\circ} \mathrm{C}$. In the case of water samples, $10 \mathrm{~mL}$ of methanol (HPLC grade, Tedia) was added to $1 \mathrm{~L}$ of sample to avoid biotransformation of chemicals during transport. One liter was filtered through $1.2 \mu \mathrm{m}$ glass fiber filters (Merck) and $0.45 \mu \mathrm{m}$ cellulose acetate filters (Merck).

Sediment was dried at $60^{\circ} \mathrm{C}$ for $24 \mathrm{hs,}$, macerated, and ten grams were taken for extracting by sonication with methanol $(10 \mathrm{~mL} ; 5 \mathrm{~min})$. Subsequently, the liquid phase was separated by centrifugation ( $2500 \mathrm{~g}$; 5 minutes) and the supernatant was collected. This procedure was repeated three times and finally ultra-pure water was added up $250 \mathrm{~mL}$.

Samples were purified using columns of solid phase extraction (SPE, Strata-X, Phenomenex $\left.{ }^{\circledR}\right)(500 \mathrm{mg} / 6 \mathrm{~mL})$. $250 \mathrm{~mL}$ of sediment extract and $1000 \mathrm{~mL}$ of water sample $(\mathrm{pH}$ 2 ), were passed through columns previously conditioned with $6 \mathrm{~mL}$ of hexane, $2 \mathrm{~mL}$ of acetone, $6 \mathrm{~mL}$ of methanol and 10 $\mathrm{mL}$ of Mili-Q water ( $\mathrm{pH} 3$ ). After loading the sample, elution was performed with $4 \mathrm{~mL}$ of acetone. The extract was dried in a gentle nitrogen stream and re suspended in $2 \mathrm{~mL}$ of ethanol for YES assay.

\section{Yeast Estrogen Screen (YES) bioassay}

Yeast strain was kindly provided by Prof. Marcia Dezotti (UFRJ, Brazil). The assay procedure was according to the original protocol (Routledge and Sumpter, 1996) following the adaptations of Bila et al. (2007). Briefly, the yeast stock stored at $-20^{\circ} \mathrm{C}$ in a cryogenic tube $(2 \mathrm{~mL})$ with growth medium and glycerol $(40 \%)$ was added to $10 \mathrm{~mL}$ of the growth medium and grew on an orbital shaker 48 hs. $100 \mu \mathrm{L}$ of culture were added for a new growth medium $(10 \mathrm{~mL})$ and grew on an orbital shaker for another $24 \mathrm{hs}$. The assay medium was prepared by mixing $25 \mu \mathrm{L}$ of the above solution, $25 \mathrm{~mL}$ of growth medium, and $250 \mu \mathrm{L}$ of the Chromogenic substrate chlorophenol red- $\beta$-D-galactopyranoside (CPRG, $10 \mathrm{mg} \mathrm{mL}$ 1). The $17 \beta$-estradiol (E2) standard solution $\left(54,48 \mu \mathrm{gL}^{-1}\right)$ and the samples extracts were serially diluted in ethanol and 10 $\mu \mathrm{L}$ of each dilution were transferred (in duplicate) into a 96well optically flat microtiter plate and allowed to evaporate until dryness. Then $200 \mu \mathrm{L}$ were seeded into 96-well test plates $\left(\mathrm{Kasvi}^{\circledR}\right)$ and each time dilution series of E2 were used as a calibration curve. Plates were sealed with masking tape and vigorously shaken on a plate shaker for $2 \mathrm{~min}$. Then plates were incubated in darkness at $30{ }^{\circ} \mathrm{C}$ during $72 \mathrm{~h}$ and absorbance was read at $540 \mathrm{~nm}$ for colour development (estrogenicity) and $620 \mathrm{~nm}$ for turbidity correction with a plate reader (Softmax Pro 5 Spectra Max M3). Limit of quantification (LQ) was determined according to INMETRO (2011), its value was $0.035 \mathrm{ng} \mathrm{g}^{-1}$ of sediment. Turbidity correction was applied in all sample extracts and standards according to Coleman et al. (2004). Estrogenic activity was calculated as E2 equivalents (E2-EQ) by interpolation from the E2 standard curves $\left(\mathrm{ng} \mathrm{L}^{-1}\right)$.

Cytotoxicity of sediment samples were obtained by measurements of inhibition of yeast cell growths by reduction of absorbance at $620 \mathrm{~nm}$, compared to reference wells (Frische et al., 2009)

\section{Statistical analysis}

In order to investigate whether estrogenicity was affected by environmental variables a Generalized Linear Model GLM (with response variable log transformed) was carried out. It includes linear regressions between estrogenicity and environmental variables, retaining those variables with significant effects. All values of parameters were transformed using exponential function for correct interpretation of values. All analyses were performed using R-statistical free package.

\section{RESULTS}

\section{Land uses and environmental quality parameters}

The drainage area of each sampling point denotes heterogeneous sizes ranging from 1 to $9122 \mathrm{Km}^{2}$ (Table 1). Land uses varied considerably between sub-basins and sampling points. The predominant land use represented in the sampling points was agriculture with a mean of $74.1 \%$ (including $3.5 \%$ of forestation with Pine spp. and Eucaliptus spp.), followed by rangelands $(21.3 \%)$ and urban-industrial (4.9\%).

Environmental variables showed a wide range of values (Table 1). Highlighting the great variation found in Total phosphorus and ammonium values (Fig. 2).

\section{Estrogenicity and cytotoxicity}

Estrogenicity was observed in 14 of the 42 sites analyzed (Fig. 3). All sub-basins showed estrogenicity except Canelón 


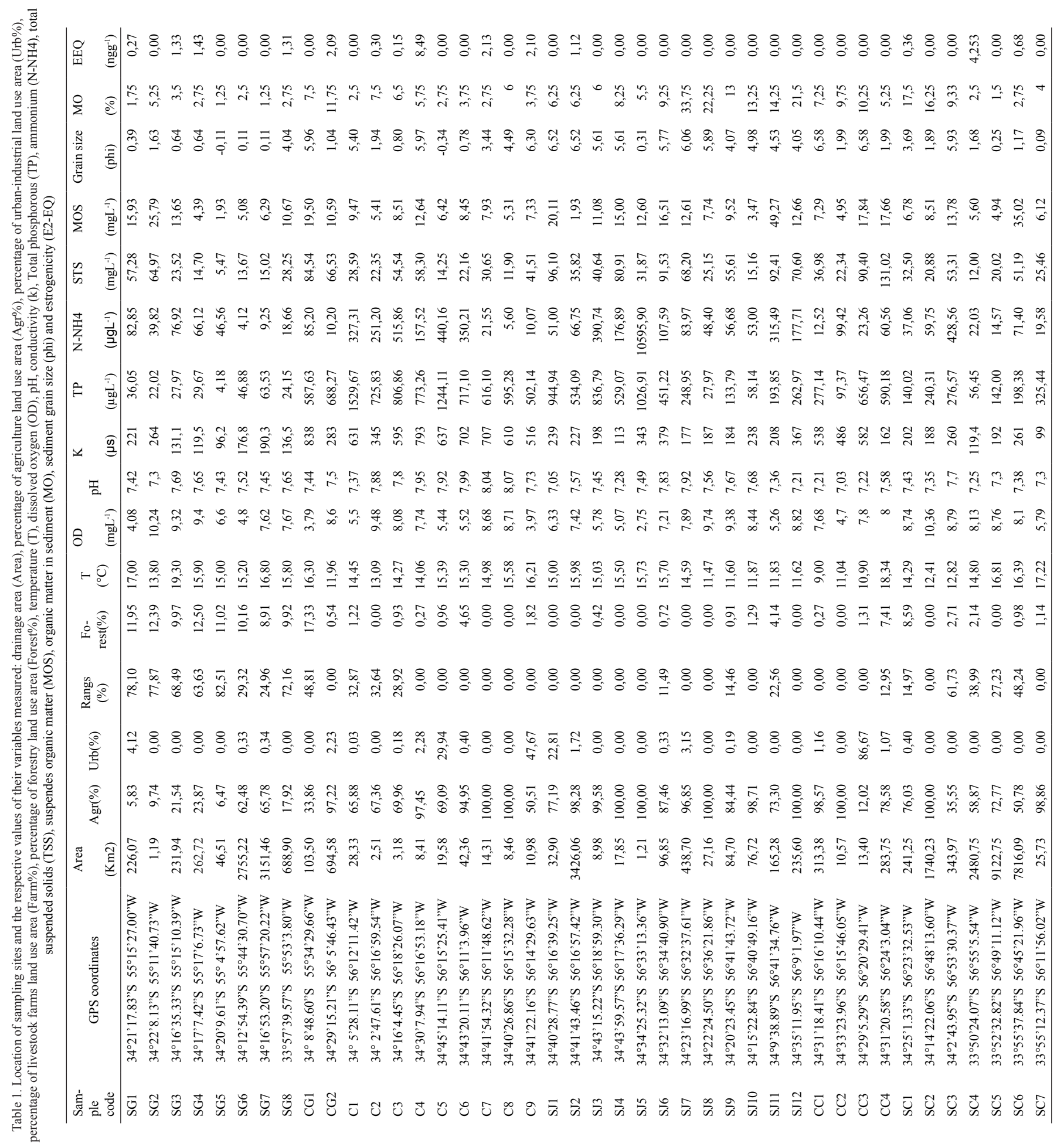




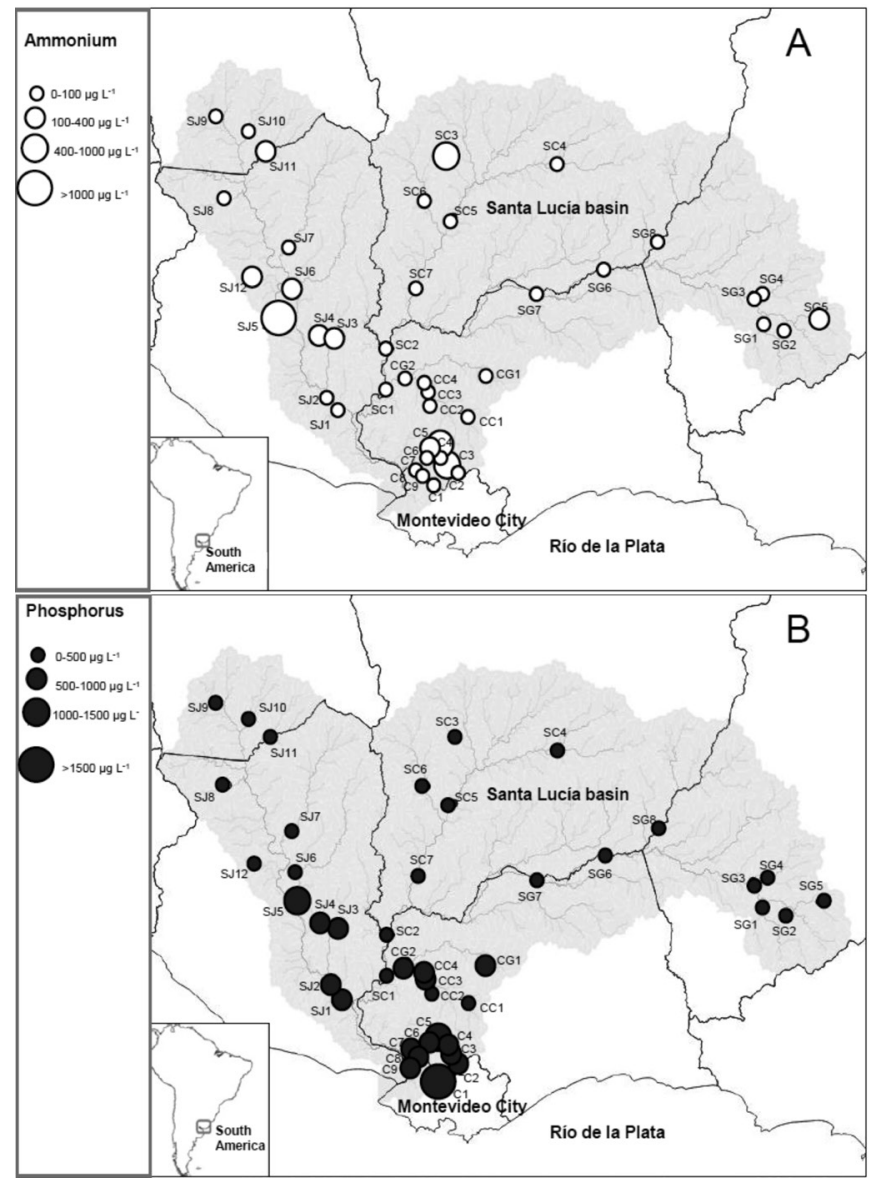

Figure 2. Distribution pattern of ammonium (A) and Total Phosphorous (B) concentrations in $\mu \mathrm{g} \mathrm{L}^{-1}$ in water samples of the Santa Lucía basin.

Chico (CC). The maximum value (E2-EQ $8.49 \mathrm{ng} \mathrm{g}^{-1}$ of sediment) was found in Colorado sub-basin (Fig. 3). Inhibition of cell proliferation (cytotoxicity) was observed in 9 sampling points, covering all land uses and sub-basins. The greatest inhibition of yeast growth (92\%) occurred downstream from the city of Progreso (Colorado stream,), which represent an important urbanized center whose water quality problems have been reported (Teixeira de Mello, 2007) (Fig. 3).

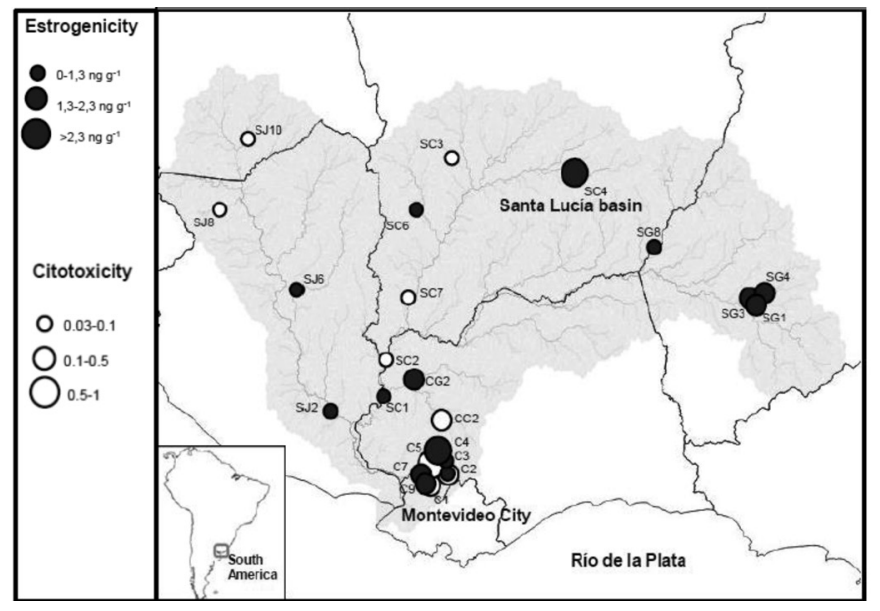

Figure 3. Toxicity of sediments along the Santa Lucía river basin. The range values of estrogenicity (E2-EQ ng g ${ }^{-1}$ of sediment) are in black circles, and cytotoxicity $(\%)$ in white circles.

\section{Estrogenicity and environmental variables}

The environmental variables that showed significant relationships with estrogenicity were total phosphorous, organic matter in sediment, urban-industrial land use area and total suspend solids (slope $=0.02,0.61,1.00$ and 0.98 respectively) (Table 2).

\section{Spatio-temporal dynamic of estrogenicity and cytotoxicity}

When estrogenicity in water and sediment samples in three sampling points (SG1, SG2 and SG4) was compared, no estrogenicity was detected in sediments during this period of study. We only found activity above the LQ in water samples of SG1 in February, in which no estrogenicity was found previously (winter). Relative low levels of cytotoxicity were found in sediments of SG4 (2\%) and in water of SG2 with 3\% of inhibition (Table 4).

\section{DISCUSSION}

Water quality parameters observed in this study confirm the eutrophication process of the Santa Lucía River, which was mainly reflected by high levels of TP and ammonium in sites associated with intensive agriculture and urban land use (Fig. 2), and is generally in agreement with other studies (Chalar et al., 2013; Goyenola et al., 2015).

The main site with serious problems of water quality was SJ5 inside San José city (both nutrient overload and low values of OD were found. Only 4 sites showed values of TP below the maximum concentration $\left(25 \mu \mathrm{g} \mathrm{L}^{-1}\right)$ established for drink water source according to national regulations (D.253/79). Many of these sites are established within watersheds with intense agricultural activity, besides the presence of major cities nearby. Therefore these sites could receive diffuse inputs of TP probably of agrochemical origin, and punctual contributions from domestic or industrial sources. In fact a marginal association between TP and agricultural $(r=0.29$, $\mathrm{p}=0.06)$ and urban $(\mathrm{r}=0.26, \mathrm{p}=0.09)$ land use was found (data not shown).

Ammonium values were also high. The maximum value (10595 $\mu \mathrm{g} \mathrm{L}^{-1}$ ) was found on SJ5 exceeding by 10 times

Table 2. Generalized Linear Model used to evaluate enviromental variables and estrogenicity relationships. Slope values of linear regressions between estrogenicity and environmental and land use variables were showed: Total phosphorours (TP), organic matter percentage (\%MO), Urban-Industrial land use area (Urb) and Total suspended solids (TSS). SE: estandar error.

\begin{tabular}{lcccc} 
Variable & Slope & SE & $\mathrm{p}$ & \\
\hline TP & 0,02 & $1.609 \mathrm{e}-03$ & $0.017 *$ & \\
\% MO & 0,61 & $1.340 \mathrm{e}-01$ & 0.00021 & $* * *$ \\
Urb & 1,00 & $3.314 \mathrm{e}-05$ & 0.00086 & $* * *$ \\
TSS & 0,98 & $1.089 \mathrm{e}-02$ & 0.039 & $*$ \\
\hline
\end{tabular}


Table 3. Spatial and temporal variation of estrogenicity and citotoxicity in water and sediments of the Santa Lucía Grande sub-basin. In bold are highlithed estrogenic and toxic values observed.

\begin{tabular}{|c|c|c|c|c|c|c|c|c|}
\hline $\begin{array}{l}\text { Sampling } \\
\text { Time }\end{array}$ & Point & $\begin{array}{c}\text { Temperature } \\
\left({ }^{\circ} \mathrm{C}\right)\end{array}$ & $\mathrm{pH}$ & $\begin{array}{c}\text { DO } \\
\left(\mathrm{mg} . \mathrm{L}^{-1}\right)\end{array}$ & $\begin{array}{c}\text { E2-EQ } \\
\text { (ng.L }{ }^{-1} \text { Water) }\end{array}$ & $\begin{array}{c}\text { E2-EQ } \\
\text { (Sediment) }\end{array}$ & $\begin{array}{c}\text { Citotoxicity } \\
\text { (Water) }\end{array}$ & $\begin{array}{r}\text { Citotoxicity } \\
\text { (Sediment) }\end{array}$ \\
\hline \multirow{3}{*}{ December } & SG1 & 26.2 & 8.1 & 8.3 & $<\mathrm{LQ}$ & $<\mathrm{LQ}$ & $<1 \%$ & $<1 \%$ \\
\hline & SG2 & 23.7 & 7.8 & 8.2 & $<\mathrm{LQ}$ & $<\mathrm{LQ}$ & $3 \%$ & $<1 \%$ \\
\hline & SG4 & 26.9 & 7.7 & 8.3 & $<\mathrm{LQ}$ & $<\mathrm{LQ}$ & $<1 \%$ & $2 \%$ \\
\hline \multirow{3}{*}{ January } & SG1 & 24.0 & 7.3 & 8.3 & $<\mathrm{LQ}$ & $<\mathrm{LQ}$ & $<1 \%$ & $<1 \%$ \\
\hline & SG2 & 25.0 & 7.3 & 8.3 & $<\mathrm{LQ}$ & $<\mathrm{LQ}$ & $<1 \%$ & $<1 \%$ \\
\hline & SG4 & 26.5 & 7.8 & 8.2 & $<\mathrm{LQ}$ & $<\mathrm{LQ}$ & $<1 \%$ & $<1 \%$ \\
\hline \multirow{3}{*}{ February } & SG1 & 28.3 & 8.0 & 8.3 & $2.4 \pm 0.2$ & $<\mathrm{LQ}$ & $<1 \%$ & $<1 \%$ \\
\hline & SG2 & 28.0 & 7.9 & 8.3 & $<\mathrm{LQ}$ & $<\mathrm{LQ}$ & $<1 \%$ & $<1 \%$ \\
\hline & SG4 & 28.5 & 8.2 & 8.3 & $<\mathrm{LQ}$ & $<\mathrm{LQ}$ & $<1 \%$ & $<1 \%$ \\
\hline
\end{tabular}

standards established by national legislation (D.253/79). These and others high concentrations are probably linked to the discharge of untreated domestic sewage. Most of the cities and villages in Uruguay do not have sewage primary treatment plant.

Estrogenic and cytotoxic activities were found in sediments of Santa Lucia Basin, in all sub-basins and associated with different land uses, reinforcing the idea that environmental estrogenicity is a multifactorial response, depending on multiple human activities, whether the sources are diffuse or punctual (Gorga et al., 2015). However, a significant relationship between estrogenicity and urban-industrial land use area was found (Table 2) which could indicate that point source discharges are contributing to the release of substances with estrogenic potential. This is particulary important in view of the fact account that sewage effluents are the major source of estrogenic compounds in the aquatic environment (Ying et al., 2009).

The presence of xenoestrogens was determined mainly from hydrophobic compounds present in the sediments, becoming our observations limited to these kind of compounds, therefore false positives are discarded while false negative could potentially exist if presence of hydrophilic estrogenic chemicals are present.

Within 14 estrogenic sites, there were urban and industrial regions, but also areas with intensive agriculture activity and livestock operation. Therefore, could be compared with other works (Table 4). In most of these works samples analyzed come from watersheds that receive raw and treated discharges from different sites. However, our values are generally higher when compared to other studies. It is emphasized that the technique used is a fairly conservative approach that is to say values were obtained with high LQ $\left(0.035 \mathrm{ng} \mathrm{g}^{-1}\right.$ of sediment $)$.

Most of estrogenic sites were located in Colorado subbasin (Fig. 3), which are associated with areas of high urbanization and agriculture (Teixeira de Mello, 2007). However, estrogenicity was found in sites that were considered of relatively low human impact. This could be associated with multiple sources that release substances which may be acting as xenoestrogens in addition to urban and agricultural activities. At Canelón Grande (CG2) and Chico (CC2) high values of estrogenicity and cytotoxicity were found. It is important to note that these streams flow in the Santa Lucía River $1 \mathrm{~km}$ upstream of a dam for extracting water for potabilization (Aguas Corrientes dam, OSE). Something similar occurs near an important city (Minas) which has treatment plant an estrogenicity was found here (SG1). These results reflect the inefficiency to remove EDCs compounds with only primary treatment plants of wastewater (Xu et al., 2012).

Table 4. Comparison of estrogenicity observed in different water bodies (mean values) in sediment and water.

\begin{tabular}{lccc}
\hline & $\begin{array}{c}\text { E2-EQ } \\
\text { Sediment } \\
\left(\mathrm{ng} \mathrm{g}^{-1}\right)\end{array}$ & $\begin{array}{c}\text { E2-EQ } \\
\text { Water } \\
\left(\mathrm{ng} \mathrm{L}^{-1}\right)\end{array}$ & References \\
Water body & 8.49 & - & This work \\
\hline Santa Lucía river (Uruguay) & 0.12 & 1.06 & Wang et al., 2011 \\
Liaohe river (China) & 24 & 14 & Zhang et al., 2011 \\
Yundang lake (China) & - & 2.0 & Alvarez et al., 2013 \\
Maryland (USA) & 1 & - & Grund et al., 2011 \\
Danube river (Germany) & - & 17 & Dias et al., 2015 \\
Paraiba do Sul river (Brazil) & 0.3 & 2.0 & Gorga et al., 2015 \\
Ebro river (Spain) & - & 2.91 & Coleman et al., 2008 \\
Browns creek (Australia) & 0.26 & - & García-Alonso et al., 2011b \\
Humber estuary (England) & - & 5.9 & Duong et al., 2010 \\
Yeongsan river (South Korea) & & \multicolumn{3}{c}{}
\end{tabular}


Besides 14 estrogenic sites, 9 points presented cytotoxicity. It is remarkable that with this approach, cytotoxic sites could contain high levels of estrogenic chemicals and not be detected.

The only site which presented both cytotoxicity and estrogenicity was at Paso Severino dam. It would be interesting to assess the estrogenicity and cytotoxicity at this point in water samples, since these waters are used for human consume and therefore is important to consider the effectiveness of the type of treatment carried out here.

Significant association between estrogenicity and environmental variables were observed (Table 2). It was particulary interesting to note the relationship between estrogenicity and organic matter in sediment, probably a consequence of greater adsorption of chemicals to organic matter.

The temporal and space estrogenicity variation observed indicate how dynamic is this aquatic system and estrogenicity in water and sediment dependent on point and diffuse sources discharges that may have occurred at certain points and times. The dynamic of estrogencity observed during temporal study and the absence of association with indicators of water quality parameters or area drainage reported at each sampling point, are consistent with the existence of multiple sources of pollutants (Gorga et al., 2015).

In addition, the analysis of land use was carried out on a large scale, but there may be multiple small-scale activities that are affecting environmental estrogenicity and therefore should be used as indicators to consider in future studies.

Finally, there may be multiple chemical compounds that can act as EDCs, and even

more depending on the presence of other organic and inorganic compounds, their bioavailability and toxicity may vary. That is why we consider the analysis of response (i.e. estrogenicity) and not the analytical quantification of a given compound as the best tool to determine the degree of environmental quality of a body of water.

\section{CONCLUSIONS}

Contamination by estrogenic substances in sediments occurs in various locations of the Santa Lucia River basin, as well as cytotoxicity, associated with multiple sources of pollutants and land uses. Water quality parameters observed in this study confirm the eutrophication process of the Santa Lucía River, which was mainly reflected by high levels of $\mathrm{TP}$ and ammonium. This work describes for first time in Uruguay the presence of estrogenic substances in the environment using a direct assay method (YES), indicating the relevance of employment of these measurements in human-sensitive watersheds.

\section{ACKNOWLEDGMENTS}

This study was supported by the National Agency for Research and Innovation (ANII) and the Development Program of Basic Sciences (PEDECIBA) from Uruguay; and by CAPES and $\mathrm{CNPq}(506.750 / 2013-2)$ foundation from Brazil.

\section{REFERENCES}

ACHKAR, M., DOMINGUEZ, R.A. \& PESCE, F. 2012. Cuenca del Río Santa Lucía - Uruguay. Aportes para la discusión ciudadana. Programa: Uruguay Sustentable. REDES, Uruguay. 25p.

ALVAREZ, D.A., SHAPPELL, N.W., BILLEY, L.O., BERMUDEZ, D.S., WILSON, V.S., KOLPIN, D.W., PERKINS, S.D., EVANS, N.W., FOREMAN, T., GRAY, J.L., SHIPITALO, M.J. \& MEYER, M.T. 2013. Bioassay of estrogenicity and chemical analyses of estrogens in streams across the United States associated with livestock operations. Water. Res. 47: 33473363. http://dx.doi.org/ 10.1016/j.watres.2013.03.028.

AYOOLA, J.A.O., GARCÍA-ALONSO, J. \& HARDEGE, J.D. 2011. Glutathione-S-transferase in Nereis succinea (Polychaeta) and its induction by xeno-estrogen. Environ. Toxicol. 26: 559565. http://dx.doi.org/ 10.1002/tox.20580.

BILA, D., MONTAlVAO, A., AZEVEDO, D.D. \& DEZOTTI, M. 2007. Estrogenic activity removal of $17 \alpha$-estradiol by ozonation and identification of by-products. Chemosphere 69: 736746. http://dx.doi.org/ 10.1016/j.chemosphere.2007.05.016.

BONILLA, S., HAAKONSSON, S., SOMMA, A., GRAVIER, A., BRITOS, A., VIDAL, L., DE LEÓN, L., BRENA, B.M., PÍREZ, M., PICCINI, C., MARTÍNEZ DE LA ESCALERA, G., CHALAR, G., GONZÁlEZ-PIANA, M., MARTIGANI, F. \& AUBRIOT, L. 2015. Cyanobacteria and cyanotoxins in freshwaters of Uruguay. INNOTEC 10: 1688-3691. : https:// www.researchgate.net/publication/289506230

CHALAR, G., DELBENE, L., GONZÁLEZ-BERGONZONI, I. \& AROCENA, R. 2013. Fish assemblage changes along a trophic gradient induced by agricultural activities (Santa Lucía, 392 Uruguay) Ecol. Indic. 24: 582-588. http:// dx.doi.org/10.1016/j. ecolind.2012.08.010.

COLEMAN, H.M., ROUTLEDGE, E.J. \& SUMPTER, J.P. 2004. Rapid loss of estrogenicity of steroid estrogens by UVA photolysis and photocatalysis over an immobilized titanium dioxidecatalyst.Water. Res. 38: 3233-3240. http:// dx.doi.org/ 10.1016/j.watres.2004.04.021.

COLEMAN, H.M., KHAN, S.J., WATKINS, G. \& STUETZ, R.M. 2008. Fate and analysis of endocrine disrupting chemicals in some sewage treatment plants in Australia. Water .Sci. Technol. 8(11): 2187-2194. http:// dx.doi.org/10.2166/wst.2008.573.

COMBALBERT, S. \& HERNANDEZ-RAQUET, G. 2010. Occurrence, fate, and biodegradation of estrogens in sewage and manure. Appl. Microbiol. Biotechnol. 1671-1692.

DE COSTER, S., VAN LAREBEKE, N., 2012. Endocrine-disrupting chemicals: associated disorders and mechanisms of action. J. Environ. Public. Health. 20(1): 12-24. http:// dx.doi.org/10.1007/ s00253-010-2547-x.

DIAS, A.C.V., GOMES, F.W., BILA, D.M, SANT'ANNA JR, G.L. \& DEZOTTI, M. 2015. Analysis of estrogenic activity in environmental waters in Rio de Janeiro state (Brazil) using the yeast estrogen screen. Ecotox. Environ. Saf. 120: 41-47. https:// doi.org/10.1016/j.ecoenv.2015.05.013.

DING, T., LÜ, C., HE, J., ZHAO, B., WANG, J., ENHE, ZHOU, H. \& ZHANG, Y. 2016. Adsorption characteristics of Pb2+ on natural black carbon extracted from different grain-size lake sediments. Environ. Sci. Pollut. Res. 23(23): 23911-23919. https:// doi. org/10.1007/s11356-016-7647-4.

DUONG, C.N., RA, J.S., CHO, J., KIM, S.D., CHOI, H.K., PARK, J.H., KYOUNG, W.K., INAM, E. \& KIM, S.D. 2010. Estrogenic chemicals and estrogenicity in river waters of South Korea and seven Asian countries. Chemosphere 78: 286-293. https:// doi. org/10.1016/j.chemosphere.2009.10.048.

EFOSA, N.J., KLEINER, W., KLOAS, W. \& HOFFMANN, F., 2017. Diclofenac can exhibit estrogenic modes of action in male Xenopus laevis, and affects the hypothalamus-pituitary-gonad 
axis and mating vocalizations. Chemosphere, 173:69-77. https:// doi.org/10.1016/j.chemosphere.2017.01.030.

FRISCHE, T., FAUST, M., MEYER, W. \& BACKHAUS, T. 2009. Toxic masking and synergistic modulation of the estrogenic activity of chemical mixtures in a yeast estrogen screen (YES). Environ. Sci. Pollut. Res. 16: 593-603.

GARCÍA-ALONSO, J., AYOOLA J.A.O., CROMPTON J., REBSCHER N. \& HARDEGE J. 2011a. Development and maturation in the nereidid polychaetes Platynereis dumerilii and Nereis succinea exposed to xenoestrogens. Comp. Biochem. Physiol. Part C 152: 196-203.

GARCÍA-ALONSO, J., GREENWAY, G.M., MUNSHI, A. GÓMEZ, J.C., MAZIK, K.A., KNIGHT, W.J., HARDEGE, D. \& ELLIOTT, M. 2011b. Biological responses to contaminants in the Humber estuary: disentangling complex relationships. Mar. Environ. Res. 71: 295-303.

GORGA, M., INSA, S., PETROVIC, M \& BARCELÓ, D. 2015. Occurrence and spatial distribution of EDCs and related compounds in waters and sediments of Iberian rivers. Sci. Total Environ. 15 (503-504): 69-86.

- GOYENOLA, G., MEERHOFF, M., TEIXEIRA-DE MELLO, F., GONZÁlEZBERGONZONI, I., GRAEBER, D., FOSALBA, C., VIDAL, N., MAZZEO, N., OVESEN, N. B., JEPPESEN, E. \& KRONVANG, B. 2015. Phosphorus dynamics in lowland streams as a response to climatic, hydrological and agricultural land use gradients. Hydrol. Earth Syst. Sci. Discuss. 12: 33493390, doi:10.5194/hessd-12-3349-2015.

GRUND, S., ERIC, H., SCHÖNENBERGER, R., SUTER, M.J.F. GIESY, J.P., BRAUNBECK, T., HECKER, M. \& HOLLERT, H. 2011. The endocrine disrupting potential of sediments from the Upper Danube River (Germany) as revealed by in vitro bioassays and chemical analysis. Environ. Sci. Pollut. Res. 18: 446-460.

INMETRO (Instituto Nacional de Metrologia, Normalização e Qualidade Industrial). 2011. Orientação sobre validação de métodos analíticos DOQ-CGCRE-008, Sao Paulo, Brazil.

JARVIS, A., REUTER, H.I., NELSON, A \& GUEVARA, E. 2008. Hole-filled seamless SRTM data 457 V4, International Centre for Tropical Agriculture (CIAT), available from $458 \mathrm{http}: / \mathrm{srtm}$. csi.cgiar.org.

KABIR, E., SHARFIN, M. \& RAHMAN, I. 2015. A review on endocrine disruptors and their possible impacts on human health. Environ. Toxicol. Pharm. 40: 241-258. http:// dx.doi. org/10.1016/j.etap.2015.06.009.

KIDD, K.A., BLANCHFIELD, P.J., EVANS, R. \& FLICK, R.W. 2007. Collapse of a fish population after exposure to a synthetic estrogen. PNAS 104: 8897-8901. http:// dx.doi. org/10.1073/pnas.0609568104.

NORRIS, D.O. \& CARR, J.A. 2006. Representative EDCs in Animals. In: Norris, D.O. \& Carr, J.A. (Eds.), Endocrine Disruption: Biological Basis for Health Effects in Wildlife and Humans. Oxford: Oxford University Press, pp. 225-463.

QUANTUM GIS DEVELOPMENT TEAM. 2015. Quantum GIS Geographic Information System. Open Source Geospatial Foundation Project. http:// qgis.osgeo.org

REHMANN, K., SCHRAMM, K.W. \& KETTRUP, A.A. 1999. Applicabilityof a yeast oestrogen screen for the detection of oestrogen-like activities in environmental samples. Chemosphere, 38: $3303-3312$.

RIVETTI, C., LÓPEZ-PEREA, J.J., LAGUNA, C., PIÑA, B., MATEO, R., ELJARRAT, E., BARCELÓ, D. \& BARATA, C. 2017. Integrated environmental risk assessment of chemical pollution in a Mediterranean floodplain by combining chemical and biological methods. Sci. Total. Environ. 583: 248-256. http:// dx.doi.org/10.1016/j.scitotenv.2017.01.061.

ROUTLEDGE, E.J. \& SUMPTER, J.P. 1996. Estrogenic activity of surfactants and some of their degradation products assessed using a recombinant yeast screen. Environ. Toxicol. Chem.15: 241-248. SÖFFKER, M. \& TYLER, C.R. 2012. Endocrine disrupting chemicals and sexual behaviors in fish--a critical review on effects and possible consequences. Crit. Rev. Toxicol. 42: 653668. http://dx.doi.org/10.3109/10408444.2012.692114.

SUMPTER, J.P. \& JOHNSON, A.C. 2008. 10th Anniversary Perspective: Reflections on endocrine disruption in the aquatic environment: from known knowns to unknown unknowns (and many things in between). J. Environ. Monitor. 10: 1476-1485. http:// dx.doi.org/10.1039/b815741n.

TEIXEIRA-DE MELLO, F. 2007. Efecto del uso del suelo sobre la calidad del agua y las comunidades de peces en sistemas lóticos de la cuenca baja del Río Santa Lucía (Uruguay). Tesis de Maestría. Facultad de Ciencias, UdelaR 46 pp.

THONGPRAKAISANG, S., THIANTANAWAT, A. RANGKADILOK, N., SURIYO, T. \& SATAYAVIVAD, J. 2013. Glyphosate induces human breast cancer cells growth via estrogen Receptors. Food. Chem. Toxicol. 59: 129-136. http:// dx.doi.org/10.1016/j.fct.2013.05.057.

VANDENBERG, L.N., BLUMBERG, B., ANTONIOU, M.N., BENBROOK, C.M., CARROLL, L., COLBORN, T., EVERETT, L.G., HANSEN, M., LANDRIGAN, P.J., LANPHEAR, B.P., MESNAGE, R., VOM SAAL, F.S., WELSHONS, W.V. \& PETERSON MYERS, J. 2017. Is it time to reassess current safety standards for glyphosate-based herbicides?. J. Epidemiol. Community. Health. 71(6): 613-618. http:// dx.doi.org/10.1136/ jech-2016-208463.

VIZZIANO, D., SAONA, G., FRANCO, J. \& NAGY, G. J. 2001 Environmental characterization of the spawning area of the white croaker, Micropogonias furnieri, in the frontal zone of the Río de la Plata. In: Vizziano, D., Puig, P., Mesones, C. \& Nagy, G. J. (Eds.), The Río de la Plata. Research to manage the environment, fish resources and the fishery in the saline front. Montevideo: Ecoplata-UNESCO, pp. 108-125.

WANG, L.,YING, G., ZHAO, J., LIU, S.,YANG, B., ZHOU, L., TAO., R.. \& SU, H. 2011. Assessing estrogenic activity in surface water and sediment of the Liao Riversystem in northeast China using combined chemical and biological tools. Environ. Poll. 159: 148-156. http:// dx.doi.org/10.1016/j. envpol.2010.09.017.

WU, C., HUANG, X., LIN, J. \& LIU, J. 2015. Occurrence and fate of selected endocrine-disrupting chemicals in water and sediment from an urban lake. Arch. Environ. Contam. Toxicol. 68: 225236. http://dx.doi.org/10.1007/s00244-014-0087-6.

XU, N., XU, Y.F., XU, S., LI, J. \& TAO, H.C. 2012. Removal of estrogens in municipal wastewater treatment plants: a Chinese perspective. Environ. Pollut. 165: 215-224. . http:// dx.doi. org/10.1016/j.envpol.2011.12.025.

YING, G.G., KOOKANA, R.S., KUMAR, A. \& MORTIMER, M. 2009. Ocurrence and implications of estrogens and xenoestrogens in sewage effluents and receiving waters from South East Queensland. Sci. Total. Environ. 407: 5147-5155. http:// dx.doi. org/10.1016/j.scitotenv.2009.06.002.

ZHANG, X., GAO, Y., LI, Q., LI, G., GUO, Q. \& YAN, C. 2011. Estrogenic compounds and estrogenicity in surface water, sediments, and organisms from yundang Lagoon in Xiamen, China. Arch. Environ. Contam. Toxicol. 61: 93-100. http:// dx.doi.org/10.1007/s00244-010-9588-0.

ZHENG, W., LI, X., YATES, S.R. \& BRADFORD, S.A. 2012. Anaerobic Transformation Kinetics and Mechanism of Steroid Estrogenic Hormones in Dairy Lagoon. Water. Environ. Sci. Technol. 46(10): 5471-8. http:// dx.doi.org/10.1021/es301551h.

\section{Web references}

http://www.mvotma.gub.uy/ciudadania/item/10003601decreto-253-079.html Last accessed 13/07/2017. 